\title{
The Adventures of Casanova as a Young Woman
}

\begin{abstract}
Ailsa Kay
Le texte d'Ailsa Kay s'approprie, pour les mémoires d'un sujet désirant féminin, la notoriété sexuelle de l'aventurier et "tombeur de ces dames" du dix-huitième siècle, G.J. Casanova de Seingult. Le récit retrouve Casanova sur son chemin de retour en direction de la ville après un séjour passé au couvent après une peine d'amour. La ville de ses souvenirs est le paysage familier du réalisme mais sur la route de gravier rien n'est ce qu'il sembleêtre. Tout comme les lignes de la main de Casanova, il y a du "brio et de la ruse et de l'audace; crise et chagrin et amour extatique aveuglant, les lignes entrecroisées vertigineuses de possibilités."
\end{abstract}

\section{Chapter 1}

After leaving the convent I learn how to gamble and make a friend. Monsieur Lupin and Mademoiselle Caron eat figs. Reflections.

They're smooth and hot and small. Small as peas, smooth as the skin of Henry's hot and fevered cheek that, only five months ago, I washed in cool water from a tin cup, thinking I would die of love. I pass the small hot pebbles from my left hand to my right and back. I shake my closed hands in front of the stranger's face, not insolently - I have no desire to be insolent - but with the calm charm required of a gambler. I cup my hands together and breathe into them. Shake the pebbles again. A bet. Just a small bet. A wager to while away the time, the two of us standing here by the side of a dusty gravel road waiting for the next carriage to come by and possibly stop and offer us a lift to the next town before we perish in the heat. He's considering his options, his eyes on my moving hands, my bejewelled fingers flashing in the harsh sun. Except for my flashing hands I am absolutely still. He scuffles the gravel, reaches a hand into the pocket of his jeans and withdraws a fifty-dollar bill.

The convent was my solution to losing love. After bathing Henry's 
fevered skin in cool water, combing the hair from his face and spooning mashed fruit between his lips, he recovered and left me. I went to the pool, as was my habit every Wednesday, and returned to our apartment to find that he had fled; a handful of plum pits on the dining room table and a section of the morning paper on the bathroom floor the only indications that he had ever been there. All his clothes, his books, his notepad computer gone. And nothing to tell me why. For three days I walked from the bedroom to the living-room to the kitchen, thinking I'd find a message. Nothing. I walked up and down our street, staring up into the branches of maple trees, prodding the lawns with my walking stick, peering down alleys. I don't know what I expected to find there. For a while I thought he must have been kidnapped and kept an eye out for a ransom note or his dead body, cold naked foot protruding from a trash can, but of course I was deluding myself. When the week was through and I'd heard nothing from him I finally allowed myself to despair. I howled. I lay on the floor with my cheek against the cold linoleum and wept. I went to bed sobbing, I woke up sobbing. I wanted to die except I knew my love was still alive and I couldn't bear the thought of him outliving me.

When I told the five nuns of Saint Anne of Grace of my despair and of my loss they fluttered strong light arms around me, touching my forehead, my hands, soothing my back with their fingers. They took me in, swept me up in those arms and carried me into the cool filtered light of the cloister.

My first night at the convent I woke up with my hand between my legs, Henry before my eyes. My sleep was betraying me, throwing images of love at my unsuspecting, unprotected imagination, making me dream of him.

I met Henry wet. Five laps around an Olympian pool I chased him, his flashing red swimsuit always just out of my reach, his laughter stretching over the sound of our splashing limbs to bounce off the high concrete walls. When finally I caught hold of him, with only the slip and pull of lycra between us, he smiled up at me and dared me to follow him. Of course I did. Like a dog I am, when it comes to Henry; I would have followed him on all fours across the width of the city had he only asked. $\mathrm{He}$ led me away from the vast and echoey indoor pool through the men's changeroom causing a stir and flurry of towels as they caught sight of my long hair and breasts, through the sauna room where men lolled, eyes 
closed, unaware of my femininity as I passed, down a short flight of stairs into the warm and humid sous-sol where the ancient and creaking workings of the pool were housed.

The seduction was fast and frantic. When I yanked down his trunks his pretty cock bobbed up at me; I took him in hand. I could hear the splash of swimmers above us, the sound blunted by water and concrete. The gurgle and hiss of pipes. Low rumble of moving deep water. I bent him over a pipe and watched the thrust of his flawless white ass as he fucked the palm of my hand. I was dripping. Standing in a puddle of water, his legs spread, thin arms cradling the pipe he was quick and hard and I imagined warm water around us, lapping at my thighs. Edging clear of my own suit, I rode him.

When I woke up in the middle of the night I drew my wet fingers across my face, through my hair, over my pillow. I couldn't smell myself. Like a ghost or a piece of glass I was without scent. I should have gotten used to it by now but it was always a shock; I had lost my sense of smell, too, to Henry. Henry: I watered my bed with tears I thought would never end, moaned his name into the thin mattress, hugged my bony knees to my chest and imagined they were his.

The two pebbles at rest in my right hand are sweaty now, and cool. It's a fifty-dollar bill or my honour and without a doubt I need the money. I'm thinking of food, to keep my mind and face blank as he makes up his mind, his eyes on me. I'm thinking of fresh cilantro, crushed between my fingers and yellow sweet pears and thick sweet steak, juice running down my chin. He points to my right fist and I open it to reveal my brilliant future: life-line strong and prosperous, wisdom line dangerously branched. Not a bit of a stone (the pebbles clenched in my left).

Minutes after taking my gambler's fifty dollars and bidding him a goodday, a carriage finally stops to pick me up and I introduce myself: "Casanova, pleased to meet you." They are Monsieur Lupin and Mademoiselle Caron. They offer me figs and I take one, pausing, as its thick syrup fills my mouth, to reflect on the vagaries of this life. 


\section{Chapter 2}

The luck foretold by my own hand wins me fifty dollars and Mademoiselle Caron experiences a lust for adventure.

He was a polite loser, the gentleman by the side of the road, and he bowed as he handed me the fifty dollars. "Outwitted by a girl," he said. "My friends will certainly laugh at my expense when they hear this story."

Not to be outdone in the ways of society, I responded, "It was not my wit, monsieur, merely my luck. You see how my palm predicts only good fortune on sunny days." I held out my hand for his inspection.

His breath on my skin as he bent close was humid. "Yes, I see." $\mathrm{He}$ straightened and I did too, to meet his gaze. "Perhaps we will meet again on a cloudy day," he said. I nodded, and he walked away.

I was tossing stones at a fence post when Monsieur Lupin and Mademoiselle Caron drew to a halt beside me. They were going as far as the next inn which suited me fine as I'd been on the road for hours already. I'd gotten only five miles from the convent on foot, and would be only twenty miles from it when we stopped but I was in no hurry to reach the city. What would I find there, after all? An empty fridge, a cold bed, a pile of laundry on the couch where I'd left it. No love. No warm Henry with his lovely little cock that curled into me as we slept side by side. Monsieur Lupin offered me another fig and I had to decline, for fear of my bowels embarrassing me later. He and Mademoiselle Caron ate and ate and I wondered what kind of guts they must have to withstand such treatment.

"Have you business in the city?" Monsieur Lupin asked, wiping his chin with the lavender handkerchief he kept tucked in his waistcoat pocket.

"No, though I will certainly have to find some once I'm there." $\mathrm{He}$ smiled politely as if he hadn't understood. "I live in the city," I said. "I've been away for a few months and I will need to find employment when I return."

"Travelling?" asked Mademoiselle Caron, her interest in me piqued by the thought of adventure. "Have you been travelling?" Until then she'd been leaning against the wall of the carriage, fiddling with the lace on her sleeve, moving only to take another fig which she then held between her teeth like a child, sucking loudly. Now she leaned toward me ever so slightly smiling as though - despite the dustiness of my jeans, the smell of my sweat, the lank oiliness of my hair - as though I were the most 
delightful person she'd ever met.

"Exactly the opposite."

"I'm sorry?"

"I've been very, very still," I said, remembering the sound of the sisters' habits swishing over the stone floors on their way to mass, their sweet trebly voices raised in praise, the gentle ribaldry of the communal shower room.

There is pleasure, I learned at the convent, in stillness, in knowing the borders of the world one inhabits. I spent hours in the garden by the south wall with the warm stone at my back, the sun a soft yellow on my cheeks. I could see, from my position on the bench, the wall of the convent itself at the north, the walls of its enclosure to the east and west. This was the earthly space allotted me, I thought, and felt happy. I learned the names for all the herbs grown in the garden, of all the trees in the orchard, of all the nuns buried in the cemetery at the south-east corner. I learned how to walk with smaller strides, making my territory seem larger. I slowed every movement, allowed gestures and sounds to last. For four months, I had no other desire.

\section{Chapter 3}

A valuable brooch. A story of love entertains my benefactress.

Mademoiselle Caron was regarding me strangely. She was eyeing my beautiful jewellery: flashing rubies and emeralds set in the softest gold. My brooch was the most valuable of all my possessions, though only one familiar with the work of Monsieur Fumier would recognize it as such. It looked like an ordinary gold engraved brooch, the size of a pocket watch, studded with chips of emerald. But one of those chips was a tiny mechanism which, if pressed, swung the brooch open to reveal an ornate miseen-scene: a woman, dress torn to reveal her breasts and cunt, leaned back in a chair as a dog nuzzled between her legs and a well-clothed man stroked his prick as he watched from another chair. The details of furniture and clothing were exquisite but required a magnifying glass to see. Monsieur Fumier produced only six miniature works of art like this in a year. He painted them with a strand of hair plucked from the head of his mistress. Only her hair, he had told me once, had precisely the flexibility, 
strength and fine ends required for his work. He had set by a braid of it, in case she ever left him.

"What did you say you've been doing so far from the city?" Mademoiselle Caron asked, with a rustle of silk as she moved closer to me.

"I'm sorry, Mademoiselle, I don't believe I did say."

"Surely it's not a secret," she smiled and ran a finger along the edge of lace at her bust. She was charming, I thought, more charming than I'd noticed at first. Monsieur Caron was asleep on the bench opposite us. The carriage rode smoothly, the horses moving at a steady pace, the only sound their hooves on the gravel of the road, occasionally a half-hearted, automatic, "hiyee" from the driver. While it was certainly cooler in the carriage than outside, I was still damp with sweat and wanted more than anything to be left in peace to contemplate my return to a city without Henry. I needed to plan. I needed to remember places and streets, reinscribe the map of it on my brain. She leaned still closer and whispered in my ear: "And even if it were, I wouldn't tell."

"I've been meeting with the five young princes of Georgia," I said, "and schooling them in the arts of poetry and love."

Mademoiselle Caron laughed low in her throat and put her hand on my knee. "Fascinating!" she said. The story entertained us both for the remainder of the journey as our travelling companion slept on, oblivious to our fun.

\section{Chapter 4}

I am betrayed by my nose and my charming companion. My gambling friend appears to be quicker than $I$.

We tumbled from the coach flushed and disordered. I had thought to tuck the fifty-dollar bill into my shoe when I received it, a safeguard for which I congratulated myself now for Mademoiselle's explorations would otherwise surely have made her that much wealthier. I beckoned to the stable boy to rouse Monsieur Lupin from his stupor and escort him to a room. He poked his head into the carriage and immediately backed out, hand to his nose.

"What?" I asked, concerned, suddenly, for the well being of our companion. At the tone of my voice, Mademoiselle Caron stopped giggling 
and we both looked to the stableboy for explanation.

"It fuckin' reeks," he said. "You can get him out yourself." He turned his back on us, shaking his head as he walked back toward the stable.

I didn't understand but Mademoiselle blushed. "The figs," she said. "We were told they were the best cure for a loveless marriage."

Now it was my turn to put a hand to my face. "You mean?"

She nodded. I'd cuckolded men before, but only men who were fools. I'd also made love to men whose wives looked on from behind a screen or through a hole in the wall. That was all in the spirit of performance, an honourable pastime. I'd never, however, been led into such a situation unaware. And such a disgusting situation! That lovely warmth between her legs! I should have known. Now I looked at my hands. They were filthy. They were filthy and my lovely Mademoiselle Caron looked at me with sly eyes. She'd had me on a leash from the moment I poked my dusty face through her carriage window. A cure for a loveless marriage! It was perverse. I cursed Henry and my miserable nose. She took my hand and ran a finger across the ridge of my knuckles, followed the curve of flesh into my palm. "Casanova," she said, "I will remember these hands with happiness. Forgive me."

"Mademoiselle," I replied tersely, "the pleasures of the heart have no place in the bowel. You have done your husband a dishonour and you have lured me into debauchery such as I have never experienced nor would ever wish to again."

I spoke with low voice into her ear as we stood beside the carriage. I would have no one know of my disgrace if I could. I would wash my hands of her. I would wash my hands of her husband. Shit. I wanted to die of shame. Turning my back on her in disgust, I strode toward the stable, in search of water.

Were it not for Henry I would still have the nose of my youth. In the eight months that we spent together he gave me one dose of flu, one common cold, and one horrifying illness that robbed me of my sense of smell. I lay in bed under heaps of afghans and kept a stack of handkerchiefs by my hand. It was absolutely inhuman the amount of mucus produced by my nose during the course of this so-called cold. Henry was worried sick. And repentant, of course, for bringing it home. He couldn't help it; he was a substitute teacher and brought home every bug the little monsters carried into the classroom but nonetheless I blamed him. When he entered the bedroom bearing steaming cups of tea or broth I balled up snotty 
handkerchiefs and threw them at his head. I demanded better TV programming; I moaned when I couldn't sleep; I made him listen to the gurgling in my congested chest.

In desperation I smeared two tissues with Vapo-Rub, moulded them into miniature corks, and shoved one into each nostril. I lay on my back, mouth wide open, and concentrated on air. At the end of it I could not smell. Henry said at least I hadn't lost a finger. Or an eye. Or the sense of taste. "Imagine," he said, "the act of eating without taste. There would be no difference between a saffron rissotto and a bowl of porridge, a delicate salmon mousse and a kraft caramel pudding, a tart autumn apple and an old potato."

"A tart autumn apple?" I said, laughing.

"Yes," he stood before me in his underwear and shirt, getting dressed for work, looking beautiful. He smiled at me, "A tart autumn apple is utterly unlike an old potato." He wiggled his charming bum at me as he left the room.

After washing myself thoroughly and rigorously at the stable pump, scrubbing myself with the burlap normally reserved for animals, I returned to the courtyard where Mademoiselle Caron stood, leaning into the carriage trying to wake her cuckolded husband. They were a pathetic pair, after all. "I will, of course, forgive you, Madame," I whispered into her ear, "as long as the world associates my name with your ecstasy - not your digestion." Though it was dusk now and I was tired, longing for nothing more than a bed and a good night's sleep, I walked away from the inn; I would offer them no opportunity for ridicule this evening. Deep in reflection, not a hundred yards down the road, I heard my name.

"Gambler!" said the voice from above, "what does your palm tell you of the night?"

\section{Chapter 5}

\section{I am challenged by a bird.}

The man whose fifty dollars was still in my shoe swung down from the oak tree where he'd been perched. He seemed pleased with himself for having startled me. Shaking the twigs and leaves from his hair, brushing the bits of bark from where they clung to his shirt, his soft breeches, he 
smiled. He must have the gift of flight, to have gotten here so quickly.

"Another go, then?" I asked, regaining my composure. "Same stakes? Your honour, this time, or fifty dollars."

He bit his lip, crossed his arms over his chest, shy now the tables were turned. I was enjoying his discomfort immensely, imagining the sound of buttons popping off his pants as he wriggled out of them, when he pointed to the brooch at my throat. "My honour," he said, "or the brooch."

My brooch - involuntarily, I raised my hand to cover it. It was my most valuable possession in the world. Not only was it worth more than any of the jewels on my fingers but I'd purchased it from the artist himself whom I'd met in Amsterdam two years earlier at the home of Madame XXX. Known for her extravagant table, our hostess had outdone herself that evening. We dined that night, Monsieur Fumier and I and six others, on fowl raised in a dark room fed exclusively on rice (exquisite), on macaroni, al sughilo (so delicate) and spicy olla podridas. The table was set with the most expensive china, the most intricate and elegant cutlery and, of course, crystal. The centerpiece (an ode to Fumier) was a slim, naked girl who sat, perfectly still, back arched and legs spread, on a chaise made of stacked fruit; oranges, pears, plums and pineapples. I have no idea what held it together. The girl was lovely. I had to pause in my dinner to stroke her fine downy skin; she didn't move a muscle. I met up with this same girl, Valencia, two months later in Toronto. She'd turned her beauty and superb muscular control to dancing, gold coins around her waist.

That evening in Venice, however, we concluded our feast with Zara maraschino and strong, bitter coffee. Truly, our hostess had exceeded all expectations; her guests were in rapture. I'd been seated next to Monsieur Fumier at my own request. I'd seen his work at the throat of a lover and thought I'd never in my life witnessed anything of such perfect beauty and intensity. I was immediately intrigued and asked my lover to tell me the story of this exquisite portrait. All he could tell me was that he'd purchased it from a man who had recently lost a fortune in shipping, that this man had purchased it from an actress, that the actress had received it from a benefactor who had commissioned it from M. Fumier, the artist, who lived in Venice. Since first laying my eyes on that brooch, I'd longed to meet its creator. I'd come to Madame XXX's without a thought for food but aching for a demonstration of the master's fine quill.

Ignoring the squeals of delight and moans of pleasure voiced by the other diners, I concentrated on his hands as he sliced his meat, as he sep- 
arated meat from bone, as he balanced his fork in the air. He regaled me with stories of his artistic adventures: the prostitute who'd stitched herself up with red silk thread, the monarch who'd posed with a naked child on his lap, the three sisters in the employ of a merchant who'd won them by illegal lottery. I, in turn, told him of my adventures. By the end of the night, I'd achieved my aim and he asked me to meet him at his studio the following day - to pose.

The stranger from the trees smiled down at me. Already he'd bent to pick two pebbles from the side of the road. "I don't believe I've introduced myself," he said, "I'm Robert."

"Casanova," I bowed, "a pleasure to make your acquaintance."

\section{Chapter 6}

Reflections. I make a choice.

Some moments stretch like water, this was one of them. Of course, I could not turn down a wager; I had at least to offer him the possibility of recuperating his earlier loss. But it is my breasts that are bared, my cunt so lovingly nuzzled by the golden retriever. Monsieur Fumier had captured, even, the mole below my left nipple. He'd painted the flush of my cheek at the dog's hot breath. Everything exact, it was a brazen perfect portrait of me. My eyes now on this strange man who was at home in trees and quicker than a horse-drawn carriage, I fingered the clasp of my precious brooch. How could I part with it? It would be a parting with myself.

Robert's black eyes were fastened on me, waiting. It was my decision this time; he held the pebbles in his hand, one of his hands. He waved his closed fists at me, not taunting, exactly, but beckoning. As if this were a gentlemanly pastime, as if we were in a parlour rather than by the side of the road. And suddenly I longed for the quiet of Henry's pale body beneath mine. I longed for the smooth length of his thigh, the calm of his soft-breathing chest, the vast peace of him; that I could float away. In the convent I'd been quiet, I'd had peace and still soft air. I'd had the warm of a stone wall at my back, the comfort of discipline, of women, of slow tendering days. I looked at my hands. In the waning light I could barely read my fortune which hardly mattered as I knew it by heart. There was no 
Henry there. There was no God or gentle sorority. There was brilliance and cunning and daring; crisis and sorrow and dazzling ecstatic love, the crisscrossing lines fairly dizzy with possibility. I could not stand to lose it, I thought, and chose a fist.

I made love to Robert in the bough of an oak, in the hollow under an oak, in the open air of a scandalous sky. I peeled the silk hose from his leg; he lassoed the moon and threaded it between my thighs. I tore the satin from my breast; he bound me and knotted me to him. We rolled each other, head over heels for miles, somersaulting great stretches of fuckery and buggery past lowing calves, sleeping sheep, scurrying rodents. We thrashed grassy hills, we razed pastures. We shouted our names: Casanova! Robert! Casanova! Robert! One over the other, over the other, our voices ecstatic with love.

When morning finally came it found us sleeping in each other's arms, head to toe, on the hill by the road where we'd started. I woke up first, stumbled free of him as he snored and mumbled in his slumber. My clothes were in a heap by the tree; I was freezing, dew on my shoulders and back. The brooch was still fastened to my blouse; I clicked it open. Such a voluptuous swoon, such a pretty face, such elegant tapered fingers tangled in the dog's golden hair. Lucky for me, Robert was no gambler. Clothing myself, wrapping his cloak around me, I sat down beside my sleeping lover to watch the sun rise. 